\title{
EFFECT OF SUPPLEMENTATION OF DRIED CHICORY (CICHORIUM INTYBUS L.) LEAVES IN DIETS ON PERFORMANCE OF DAIRY GOATS
}

\author{
Yasmin M. M. Mahmoud \\ Anim. Prod. Res. Inst. ARC, Ministry of Agric., Dokki, Giza, Egypt.
}

(Received 4/12/2020, accepted 16/3/2021)

\section{SUMMARY}

$\mathrm{T}$ This study was conducted to investigate the effect of inclusion different levels of dried chicory (Cichorium intybus L.) leaves in diets of Balady goat does on nutrients digestibilities, productive performance and some blood parameters, as well as the growth performance of their offspring. Twenty four pregnant lactating Balady goats were chosen at 1 month before parturition and divided randomly into three similar groups $(8 \mathrm{each})$ in a feeding trial, where the first group was served as control (R0) and fed the concentrate feed mixture (CFM) without any supplementation, while the second and third groups (R2 and R3) were fed CFM supplemented with dried chicory leaves (DCL) at rate of 1 and 2\%, respectively. The basal diet was formulated from 2.5 CFM of the live body weight (LBW) of goats plus $3 \mathrm{~kg} / \mathrm{d}$ fresh berseem in order to covering the nutritional requirements according to NRC (1989). Results indicated that the digestibility coefficients of most nutrients and feeding values were significantly $(\mathrm{P}<0.05)$ higher for R1 that contained 1\% DCL followed by R2 that contained 2\% DCL than those of un-received one (R0). Actual milk yield was significantly $(\mathrm{P}<0.05)$ higher with tested ration $\mathrm{R} 1$ and insignificant higher with the tested ration $\mathrm{R} 2$ than that of control ration. Otherwise, the yield of $4 \%$ FCM was significantly $(\mathrm{P}<0.05)$ higher with both tested rations than that of control one, being R1 had the highest yield significantly among the experimental dietary treatments. Most milk constituents (fat, lactose, SNF and ash, \%) did not affected by the dietary treatments, while only the contents of milk protein and TS were increased significantly especially with R1 than those of control (R0). Totally milk composition percentages tended to increase with DCL addition in ration R1 than the other tested rations R2 and control R0. There were significant differences in respect of feed intake among dietary treatments, where the values of DMI, TDNI and DCPI were higher in R1 and R2 compared with those of control one. The feed conversion ratio was appeared to be the best with R1 while, the poorest value was occurred with R0 and the tested ration R2 had the intermediate value. Kids in $\mathrm{R} 1$ ration showed the highest LBW and total weight gain at each age intervals as compared to other groups, being the lowest values were associated with R0, with no significant differences among the experimental treatments. Therefore, the results indicated that using DCL as herbal additives in the dairy goat diets at level $1 \%$ led to an improvement for nutrient digestibilities, productive performance and physiological functions of these animals.

Keywords: Goats, chicory leaves, digestibility, growth performance, milk production and blood biochemical.

\section{INTRODUCTION}

Recently, there is growing interest among the consumers related to health considerations to consume high-quality, safe and nutritious foods which is known by functional food (Kralik et al., 2012). Chicory (Cichorium intybus L.) is a typical Mediterranean plant, belonging to the family Asteraceae, indigenous to Europe, West Asia, Egypt, North America and Italy. There are many varieties of chicory having different commercial uses, with some misunderstanding about the botanical classification of such varieties. Vegetable commercial varieties (e.g., Bruxelles chicory, Treviso red chicory, Endive) all belonging to the species intybus have remarkable economic importance. Moreover, chicory forage had less dry matter and fewer structural carbohydrates, as it can remain green longer than other forage 
species. Because of such characteristics, chicory has been highly appreciated by farmers (Sitzia et al., 2006). Di Grigoli et al. (2012) mentioned that chicory forage potentially provide lasting good quality herb and the positive effect on dairy performance in grazing ewes. Also, Dylan Laws and Liz Genever (2013) reported that lambs grazed on chicory forage have similar growth performances to those grazing legumenous forage and better growth than those grazing grass based pastures and also they added that the rates of lamb growth can be $70 \%$ higher with grazing chicory in comparison to a standard grass sward. The addition of herbs into rations of farm animals could be affects positively on fatty acids composition in milk (Collomb et al., 2002) and also improved rumen fermentation and digestibility (Ando et al., 2003). Accordingly, there is greater interest in using plant extracts or medicinal herbs as alternative to manipulate ruminal fermentation and improve feed efficiency in ruminants (Hristov et al., 1999 and Wang et al., 2000).

This study aimed to investigate the effect of supplementing dairy goats' rations with two levels of chicory herb on digestibility, feeding values, productive performance and blood parameters of the experimental rations.

\section{MATERIALS AND METHODS}

This work was carried out at Sakha Animal Production Research Station, Animal Production Research Institute, Agricultural Research Center, Ministry of Agriculture.

\section{Animals and feeding trial:}

Twenty four pregnant Balady goats were chosen at 1 month before parturition with average body weight $31.5 \mathrm{~kg}$ at initial point of the trial and used to study the effect of addition 2 levels of dried chicory leaves (DCL) that classified as medical herbage into their rations on digestibility, milk production and composition, blood parameters and growth performance of their offspring as well . Animals were housed in groups ( 3 groups of 8 goats each). All experimental goats were fed ration consisted of concentrate feed mixture (CFM) and berseem. Goats in first group (control) were fed this ration without any supplementation (R0), while, the other two groups (R1 and R2) were supplemented with DCL at rate of 1 and 2\% levels of CFM, respectively. The CFM used in this experiment was consisted of $9.0 \%$ undecorticated cottonseed meal, $42.0 \%$ yellow corn, $40.0 \%$ wheat bran, $2.0 \%$ limestone, $1.0 \%$ salt, $1.0 \%$ minerals and $5.0 \%$ molasses. The daily amount of CFM was accounted at $2.5 \%$ of body weight and offered in two equal portions at 8 a.m and 16 p.m hrs, in addition $3 \mathrm{Kg}$ berseem in order to covering the nutritional requirements for goats according to NRC (1989). Fresh water was freely available at all times. Goats were continuously fed up to 3 months postpartum with their kids until the weaning time 3 months. The feeding period of kids ended after three months the body weight gain was monthly recorded.

\section{Digestibility trials:}

Three digestibility trials were conducted simultaneously with the same goats of the feeding trial (three animals from each group) during the post-partum period to determine the digestion coefficients and feeding values of the experimental rations. Acid insoluble ash (AIA) was used as natural internal marker and animals were fed individually where feed intake was recorded daily. Fecal samples of nearly $200 \mathrm{~g}$ were taken from the rectum twice daily at 8.00 am and $8.00 \mathrm{pm}$ during the 7 - consecutive days collection period. The daily samples of feces for each animal were immediately frozen at $-20^{\circ} \mathrm{C}$ until the end of the collection phase and then composited sample for each animals was prepared for analysis. The procedure of AIA was done according to the method described by Van Keulen and Young (1977). Chemical analysis of feed and feces was determined according to the method of AOAC (1995).

\section{Milk production:}

Lactating goats were housed under shaded area and hand milked twice a day (6.0 and $18.0 \mathrm{hrs})$ and milk yield was recorded weekly. Milk samples from consecutive milking were pooled and the composite sample was prepared and stored for analysis latter. Samples were analyzed for total solids according to Majenier method laboratory manual (1949), fat percentage was determined according to Gerber's method as described by Ling (1963). Milk protein content was determined using the macrokjeldahle method $(\mathrm{N} \times$ 6.38). Milk total solid percentage was determined by weighing $5 \mathrm{ml}$ milk followed by initial drying on sand bath for evaporating the excess water, then drying was completed in a drying oven at $105{ }^{0} \mathrm{C}$ for 
three hours. Milk ash content was estimated according to AOAC (1995), and lactose were calculated by differences. $4 \%$ Fat corrected milk $=0.4 \mathrm{M}+15.0 \mathrm{~F}$, Where, $\mathrm{M}=$ milk yield and $\mathrm{F}=$ fat yield.

\section{Blood parameters:}

Blood samples were taken during the middle day of the experiment being from goats and their offspring. Samples were taken from the jugular vein of animals at $8 \mathrm{am}$ hrs post feeding into heparinizedcoated tubes and plasma were separated by centrifugation at 3000 r.p.m for 20 minutes. Plasma samples were stored in deep freezer at approximately $-20{ }^{\circ} \mathrm{C}$ till chemical analysis. Plasma was used for determination of total protein (Armstrong and Carr, 1964); total albumin (Doumas et al., 1971) and globulin concentration was calculated as the difference between total protein and albumin. Assay of aspartate (AST) and alanine (ALT) aminotransferase activities were conducted according to procedures of Reitman and Frankel (1957). Total cholesterol was determined according to Allian et al. (1974) using bio Merieux test kit. Uric acid (Tietz, 1986) and plasma glucose was determined according to the procedure of Coles (1986); creatinine was determined according to Henry et al. (1974).

\section{Statistical analysis:}

The obtained data were statistically analyzed using one-way analysis of variance procedure (SAS, 2000) computer program using the following fixed model:

$$
Y_{i}=\mu+T_{i}+e_{i}
$$

Where $\mathrm{Yi}=$ The individual observation; $\mu=$ Overall mean; Ti = Effect of treatments. $(i=1,2$ and 3$)$ and ei $=$ Random error component assumed to be normally distributed. Significant differences between treatment means were determined at $\mathrm{P}<0.05$ by Duncan's multiple-range test (Duncan, 1955).

\section{RESULTS AND DISCUSSION}

\section{Chemical composition:}

The chemical composition of CFM, berseem and chicory leaves as well as the experimental rations are presented in Table (1). The proximate analysis of either berseem or chicory leaves used in this study were extremely similar in respect of its CP content, but the differences between them were highly significant respecting the other nutrients (CF, EE, NFE and ash percentages), being 30.76, 2.21, 45.83 and 7.93 for berseem vs. $16.78,3.68,52.80$ and 12.05 for chicory leaves, respectively. It could be observed that all mentioned values are in favorable of chicory leaves and in proceeding of berseem forage accordingly. Regarding the calculated composition of the experimental rations, all values of chemical composition were appeared to be so similar among the three rations.

Table (1): Chemical analysis of the experimental CFM, berseem and chicory leaves, and calculated composition of experimental rations (on DM basis, \%).

\begin{tabular}{lccccccc}
\hline Item & DM & OM & CP & CF & EE & NFE & Ash \\
\hline CFM & 88.40 & 89.82 & 15.98 & 11.54 & 3.05 & 59.25 & 10.18 \\
Berseem & 85.87 & 92.07 & 13.28 & 30.76 & 2.21 & 45.82 & 7.93 \\
DCL & 90.55 & 87.95 & 14.70 & 16.78 & 3.68 & 52.79 & 12.05 \\
Experimental rations: & & & & & & & \\
R0 & 88.16 & 95.35 & 14.75 & 7.16 & 4.12 & 69.32 & 4.65 \\
R1 & 88.18 & 95.25 & 14.82 & 7.31 & 4.11 & 69.01 & 4.75 \\
R2 & 88.20 & 95.16 & 14.88 & 7.45 & 4.10 & 68.73 & 4.84 \\
\hline$*$ R0, control ration & $R 1$, with 1\% and R2 with 2\% chicory leaves as an additive into control ration. & &
\end{tabular}

\section{Digestibility and feeding values:}

Results of nutrient digestibilities and feeding values of experimental rations are presented in Table (2). Mostly the differences among the dietary treatments respecting nutrient digestibilies were significant in favorable of the two tested rations in relation of control one. It 
could be observed that $\mathrm{R} 1$ ration that contained $1 \%$ chicory leaves was significantly $(\mathrm{P}<0.05)$ having the highest values in respect of digestibilities of DM, OM, CP and NFE followed by R2 that contained $2 \%$ chicory leaves versus the lowest values that were recorded with control one (R0). Meanwhile, digestibility of $\mathrm{CF} \%$ was significantly $(\mathrm{P}<0.05)$ increased, while digestion coefficient of EE\% was insignificantly $(\mathrm{P}>0.05)$ increased with increasing the levels of chicory herb in comparison with those of un-supplemented one. In matching with the present results, the findings of El-Basiony et al. (2015) showed that lactating goats fed diet containing $10 \mathrm{~g}$ Cichorium intybus had better utilized the diet than the control diet respecting the entire nutrient digestibilities (DM, OM, CP, $\mathrm{CF}, \mathrm{EE}$ and NFE). This preference may be due to the ability of the $C$. intybus herb to purification of the digestion track from the parasites that may affect the balance of the rumen environment and therefore adversely affect the process of digestion of different nutrients (Molan et al., 2003 and Athanasiadou et al., 2007). Practically, Clark et al. (1990) cleared that proportions of $70 \%$ leaves and $30 \%$ stems could be eligible in chicory forage because of the digestibility of leaves was remarkably higher than that of stems. Regarding the addition of herbs into rations of farm animals, it could be potentially improved the rumen fermentation and consequently digestibility of diet (Ando et al., 2003).

Table (2):Effect of experimental rations on digestion coefficients and feeding values for dairy goats.

\begin{tabular}{lcccc}
\hline \multirow{2}{*}{ Item } & \multicolumn{3}{c}{ Experimental rations } & \multirow{2}{*}{ \pm SE } \\
\cline { 2 - 4 } Digestion coefficients: & R0 & R1 & R2 & \\
DM & $66.16^{\mathrm{c}}$ & $69.92^{\mathrm{a}}$ & $68.13^{\mathrm{b}}$ & \pm 0.560 \\
OM & $68.41^{\mathrm{c}}$ & $72.72^{\mathrm{a}}$ & $70.67^{\mathrm{b}}$ & \pm 0.671 \\
CP & $67.34^{\mathrm{b}}$ & $73.89^{\mathrm{a}}$ & $72.33^{\mathrm{a}}$ & \pm 1.13 \\
CF & $39.20^{\mathrm{b}}$ & $43.54^{\mathrm{a}}$ & $44.88^{\mathrm{a}}$ & \pm 1.01 \\
EE & 77.54 & 78.52 & 78.61 & \pm 0.454 \\
NFE & $76.48^{\mathrm{b}}$ & $80.45^{\mathrm{a}}$ & $77.37^{\mathrm{b}}$ & \pm 0.687 \\
Feeding values: & & & & \\
TDN & $68.95^{\mathrm{b}}$ & $72.88^{\mathrm{a}}$ & $70.47^{\mathrm{ab}}$ & \pm 0.622 \\
DCP & $9.93^{\mathrm{b}}$ & $10.95^{\mathrm{a}}$ & $10.76^{\mathrm{a}}$ & \pm 0.176 \\
\hline
\end{tabular}

$a, b$ and $c:$ means in the same row with different superscripts are significantly $(P \leq 0.05)$ different. $S E=$ Standard error

$* R 0$, control ration, $R 1$, with $1 \%$ and $R 2$, with $2 \%$ chicory leaves as an additives in to control ration.

Collectively, the feeding value that expressed as TDN and DCP\% were seemed to be higher with both tested rations than those of the control one, but such values were significant increased with R1 and insignificant increased with R2, in comparison with those with control one (R0). Definitely, Hanafy et al. (2009) showed that using some medical herbage as feed additives in rations of growing Barki lambs could be improve the nutrient digestibilities and feeding values. Moreover, the findings of recent report on chicory forage that prepared by some researchers have been cleared that such forage potentially contained a reasonable contents of mineral, highly palatable with good digestion coefficients for livestock and poultry (Sanderson et al., 2003 and Scharenberg et al., 2007). El-Bordeny et al. (2008) concluded that supplementing lamb rations with 1.5 of chamomile flower as a natural feed additives improved nutrient digestibilities, nitrogen retention, daily gain and economic efficiency. Generally, the present results are in harmony with those reported by El-Basiony et al. (2015) who added $10 \mathrm{~g} / \mathrm{h} / \mathrm{d}$ into dairy goats' diets of Cichorium intybus had led to significant improvement in digestibility and consequently the feeding value of the supplemented diet in comparison with the free one. Generally, the addition of herbs into the rations of ruminants has a positive effect of rumen fermentation and digestibility (Ando et al., 2003).

\section{Milk yield and composition:}

Results of daily milk yield and its composition of goats fed the dietary treatments are illustrated in Table (3). Results demonstrated that actual milk yield was significantly $(\mathrm{P}<0.05)$ higher for goats received $1 \%$ DCL diet $(\mathrm{R} 1)$ and insignificant $(\mathrm{P}>0.05)$ higher with those fed on $2 \%$ DCL diet (R2) 
compared to that of control ration (R0). While, the yield of 4\% FCM was significant higher for both tested rations (R1 and R2) than that of control one (R0), being R1 had significant higher yield of $4 \%$ FCM than that of R2. Milk composition of goats including the percentages of fat, protein, lactose, total solids (TS), solids not fat (SNF) and ash are presented in Table (3). Results showed that R1 was significantly $(\mathrm{P}<0.05)$ improved protein and total solid in milk, while $\mathrm{R} 2$ insignificant improved protein content and significant increased the milk total solid content, based on the control (R0) values. Milk composition tended to increase with chicory addition in R1 than the other rations (R0 and R2), respecting fat and SNF with no significant differences among the experimental treatments. Concerning fat and protein yields in milk, its values were superior with $1 \%$ dried chicory $\mathrm{R} 1$ than those of control one and the other tested ration R2. Similar trend of changes in milk yield of goats was observed by El-Basiony et al. (2015) who indicated that using Cichorium intybus as additive in the dairy goats diets led to improvements for nutrient digestibilities and milk quality and quantity. The addition of herbs into rations has a positive effect on fatty acids composition in milk (Collomb et al., 2002). Additionally, Dylan Laws and Liz Genever (2013) reported that lambs grazed on chicory forage have similar growth performance to those grazing legume forages and better growth than those grazing grass-based pastures. Also, trials with dairy cows in the southern hemisphere and from the US, have shown that grazing chicory forage can increase milk solid yields in comparison to more common grass types.

Table (3): Effect of experimental rations on daily milk yield and milk composition for dairy goats.

\begin{tabular}{lcccc}
\hline \multirow{2}{*}{ Item } & \multicolumn{3}{c}{ Experimental rations } & \multirow{2}{*}{ \pm SE } \\
\cline { 2 - 4 } & R0 & $\mathrm{R} 1$ & $\mathrm{R} 2$ & \\
\hline Initial body weight (kg) & 30.60 & 33.20 & 30.80 & \pm 0.50 \\
Final body weight (kg) & $38.00^{\mathrm{b}}$ & $41.00^{\mathrm{a}}$ & $39.80^{\mathrm{ab}}$ & \pm 0.424 \\
Milk yield (kg) & $1013.3^{\mathrm{b}}$ & $1212.2^{\mathrm{a}}$ & $1149.3^{\mathrm{ab}}$ & \pm 32.78 \\
4\% FCM (kg) & $901.4^{\mathrm{c}}$ & $1090.3^{\mathrm{a}}$ & $1019.8^{\mathrm{b}}$ & \pm 30.21 \\
Milk composition and yields: & & & & \\
Fat (\%) & 3.27 & 3.33 & 3.25 & \pm 0.045 \\
Fat yield (g) & $33.07^{\mathrm{b}}$ & $40.36^{\mathrm{a}}$ & $37.33^{\mathrm{b}}$ & \pm 1.19 \\
Protein (\%) & $2.67^{\mathrm{b}}$ & $3.18^{\mathrm{a}}$ & $2.97^{\mathrm{ab}}$ & \pm 0.086 \\
Protein yield (g) & $27.19^{\mathrm{b}}$ & $38.63^{\mathrm{a}}$ & $34.10^{\mathrm{ab}}$ & \pm 1.89 \\
Lactose & $4.42^{\mathrm{b}}$ & 4.51 & 4.79 & \pm 0.107 \\
Total solids & $11.17^{\mathrm{b}}$ & $11.74^{\mathrm{a}}$ & $11.69^{\mathrm{a}}$ & \pm 0.116 \\
Solid not fat (SNF) & 7.18 & 7.40 & 7.23 & \pm 0.262 \\
Ash (\%) & 0.81 & 0.72 & 0.68 & \pm 0.030 \\
\hline
\end{tabular}

$a, b$ and $c$ : means in the same row with different superscripts are significantly $(P \leq 0.05)$ different. $\quad S E=$ Standard error. $\quad * R 0$, control ration, $R 1$, with $1 \%$ and $R 2$, with $2 \%$ chicory leaves as an additives in to control ration.

\section{Feed consumption and feed conversion:}

Results of DM intake by lactating goats during the experimental period are summarized in Table (4). The values DMI, TDNI and DCPI were significant $(\mathrm{P}<0.05)$ higher for both tested rations $(\mathrm{R} 1$ and $\mathrm{R} 2)$

Table (4): Feed intake and feed conversion of lactating goats fed the experimental rations.

\begin{tabular}{|c|c|c|c|c|}
\hline \multirow{2}{*}{ Item } & \multicolumn{3}{|c|}{ Experimental rations } & \multirow{2}{*}{$\pm \mathrm{SE}$} \\
\hline & R0 & $\mathrm{R} 1$ & $\mathrm{R} 2$ & \\
\hline \multicolumn{5}{|l|}{ Feed intake (kg /head/day): } \\
\hline DMI & $1027^{\mathrm{c}}$ & $1038^{\mathrm{b}}$ & $1053^{\mathrm{a}}$ & \pm 2.35 \\
\hline TDNI & $708.0^{c}$ & $732.0^{b}$ & $767.0^{\mathrm{a}}$ & \pm 3.32 \\
\hline DCPI & $102^{b}$ & $112^{\mathrm{a}}$ & $115^{\mathrm{a}}$ & \pm 0.949 \\
\hline $4 \%$ FCM (kg) & $901.4^{c}$ & $1090.3^{a}$ & $1019.8^{b}$ & \pm 30.21 \\
\hline \multicolumn{5}{|l|}{ Feed conversion (kg/gain): } \\
\hline DMI / FCM & $1.14^{\mathrm{a}}$ & $0.96^{\mathrm{b}}$ & $1.04^{\mathrm{ab}}$ & \pm 0.026 \\
\hline TDNI / FCM & $0.767^{\mathrm{a}}$ & $0.656^{\mathrm{b}}$ & $0.723^{a b}$ & \pm 0.017 \\
\hline
\end{tabular}


than those of control one (R0), and also the values of R2 respecting only DMI and TDNI were higher significantly than those of R1, but differences between them did't significant regarding DCPI value. While, Minnee et al. (2017) reported that inclusion up to 20 or $40 \%$ chicory (Chicorium intybus L.) in dairy cattle diet at late lactation by using grazing system could be decrease DMI and milk yields in comparison with grass-based swards diet. On the other hand, Volk and Marounek (2011) showed that no significant differences in rabbits feed intake and daily weight gain were found between chicory root- ration and the chicory free one. Also, Ivarsson et al. (2011) showed that no differences in feed intake and daily gain for weaned piglets fed a cereal-based diet including either chicory (Cichorium intybus) or ribwort (Plantago lanceolata L.) forage.

In respect of the feed conversion trait (Table 4) the best values that expressed as DMI/FCM and TDNI/FCM were occurred with 1\%-DCL ration (R1), while the poorest one was found with control one (R0), while the $2 \%$-DCL ration (R2) was occurred in between. These results are in agreement with those obtained by Boraei et al. (2013) who recommended to potentially have to be utilize the medicinal herbs as feed supplements to the rations of growing lambs, since it led to an improvement $(\mathrm{P}<0.05)$ for lambs ruminal measurements, increased feed intake, accelerated daily gain, feed utilization and maximize the net profit value/kg gain. While, Volk and Marounek (2011) recorded that there were no significant effect respecting feed conversion ratio with rabbits fed chicory root inclusion diet compared with those fed the free one. Also, Ivarsson et al. (2011) reported that no significant differences in feed conversion ratio in case of weaned piglets fed cereal-based diet with inclusion either chicory or ribwort forage. Feed conversion ratio was improved with the rabbits diet containing $20 \%$ chicory pulp compared to that of control diet (Guermah and Maertens, 2012).

\section{Body weight changes for kids:}

Live body weight (LBW) and daily weight gain for kids at intervals from birth up to three months of age are presented in Table (5). No significant differences in birth weight for kids among the experimental dietary treatments were observed. Almostly, kids in R1 showed the highest LBW and total weight gain at each age interval as compared to other groups, being the lowest values were associated with R0. The present results are supported by Di Grigoli et al. (2012) who emphasized on the potential of chicory forage to provide lasting good quality herb and the positive effect on dairy performance in grazing ewes. In a recent study, Dylan Laws and Liz Genever (2013) reported that lambs grazed on chicory forage have similar growth performances to those grazing legumes forage and better growth than those grazing grass based pastures and also they added that the rates of lamb growth can be $70 \%$ higher with grazing chicory in comparison to a standard grass sward. Furthermore, Allam et al. (2007) obtained the best findings of growth, meat quality and economic efficiency of production in Zaraibi kids due to the addition of some medicinal herbs like blackseed, chamomile, anise seeds and mint to their diets. Similarly, Boraei et al. (2013) recommended to utilize medicinal herbs as feed supplements to rations of growing lambs, since it led to accelerated daily gain, feed utilization and maximize the net profit value $/ \mathrm{kg}$ gain. Likewise,

Table (5): Effect of experimental rations on body weight and daily gain of kids.

\begin{tabular}{lccrc}
\hline \multirow{2}{*}{ Item } & \multicolumn{4}{c}{ Experimental rations } \\
\cline { 2 - 5 } & $\mathrm{R} 0$ & $\mathrm{R} 1$ & $\mathrm{R} 2$ & $\pm \mathrm{SE}$ \\
\hline Body weight $(\mathrm{g} / \mathrm{h} / \mathrm{d}):$ & & 4.10 & 4.02 & \pm 0.33 \\
Birth weight $(\mathrm{kg})$ & 4.05 & 9.18 & 9.01 & \pm 0.71 \\
Weight $(\mathrm{kg}) / 1^{\text {st }}$ month & 8.40 & 12.40 & 12.35 & \pm 0.88 \\
Weight $(\mathrm{kg}) / 2^{\text {nd }}$ month & 11.45 & 16.91 & 15.96 & \pm 0.98 \\
Weight $(\mathrm{kg}) / 3^{\text {rd }}$ month & 15.00 & & & \\
Daily gain $(\mathrm{g})$ : & & 169 & 166 & \pm 21.45 \\
From birth to $1^{\text {st }}$ month & 145 & 107 & 112 & \pm 18.05 \\
From $1^{\text {st }}$ to $2{ }^{\text {nd }}$ month & 102 & 150 & 120 & \pm 16.22 \\
From $2^{\text {nd }}$ to $3^{\text {rd }}$ month & 118 & 142 & 133 & \pm 14.10 \\
From birth to $3{ }^{\text {rd }}$ month & 122 & 150
\end{tabular}

$* R 0$, control ration, $R 1$, with $1 \%$ and $R 2$, with $2 \%$ chicory leaves as an additives in to control ration. 
Ivarsson et al. (2011) reported that inclusion up to $160 \mathrm{~g}$ chicory forage $/ \mathrm{kg}$ diet for weaned piglets did not negatively affect performance and was promising as feedstuffs for these animals. Also, in line with the present results, Yusrizal and Chen (2003) and SooBo (2005) recorded that addition chicory or inulin were affect growth performance positively in monogastric animals (rabbit, chicken, pig and rat), especially in young animals. Also, Castellini et al. (2007) and Attia et al. (2014) showed that root and forage of chicory are of interest as fiber source in poultry nutrition.

\section{Blood parameters:}

The values of some blood constituents of goats fed the different experimental rations are presented in Table (6). Results showed that the differences in concentrations of total protein, albumin, globulin, glucose, total cholesterol, aspartate (AST) and alanine (ALT) aminotransferase activities among the dietary treatments of goats were not significant. Meanwhile, plasma uric acid and creatinine concentrations were remarkably decreased in treated groups as compared to those of control one, being the lowest values occurred in tested ration (R1). Similar results were reported by El-Basiony et al. (2015) who recorded that slightly increases of each blood serum total protein, globulin, glucose, and in the meanwhile albumin, AST and ALT, cholesterol and urea concentrations were slightly decreased in diet of goats that supplemented with $10 \mathrm{~g}$ cichorium intybus/h/d compared with the control group that free from chicory. These results are in agreement with El-Saadany et al. (2008) who worked on lactating Zaraibi goats. Recently, Mahmoud (2017) pointed that rabbits fed diet contained 1\% dry chicory leaves (DCL) had the highest $(\mathrm{P}<0.05)$ concentrations of total blood protein, albumin, globulin, AST and ALT, whereas, the lowest values $(\mathrm{P}<0.05)$ was associated with $2 \%$ DCL compared with those of control one. Similarly, Allam et al. (2007) mentioned that decreased plasma cholesterol and total lipids in Zaraibi kids due to the addition of some medicinal herbs as blackseed, chamomile, anise seeds and mint to their diets. While, Mahmoud et al. (2014) found that with calves born from cows fed ration supplemented with $1 \%$ basil, globulin concentration was significantly higher in their blood compared with those born from cow fed $2 \%$ basil supplementation and the control one, otherwise all the rest of blood metabolites didn't significant affected by such additives. Definitely, Hanafy et al. (2009) concluded that using some medical herbage as feed additives in rations of growing Barki lambs could be improve the nutrient digestibilities, feeding values, daily gain and decrease serum cholesterol concentration which are favorably reflected on lambs performance and economic efficiency. On the other hand, serum total cholesterol, LDL and triglycerides concentrations were significantly $(\mathrm{P}<0.05)$ decreased in broiler chickens group fed on basal diet plus $200 \mathrm{ppm}$ of both Nigella sativa and chicory extract compared to those of control group that free from herb (Behboud Jafarilet al., 2011). In line with the present results El-Basiony et al. (2015) mentioned that the control ration had significantly the highest level of creatinine when compared with that of goats fed diet supplemented $10 \mathrm{~g}$ Cichorium intybus/h/d.

Table (6): Effect of experimental rations on blood parameters of lactating goats.

\begin{tabular}{|c|c|c|c|c|}
\hline \multirow{2}{*}{ Item } & \multicolumn{4}{|c|}{ Experimental rations } \\
\hline & R0 & R1 & $\mathrm{R} 2$ & $\pm \mathrm{SE}$ \\
\hline Total protein $(\mathrm{g} / \mathrm{dl})$ & 8.53 & 8.72 & 8.47 & \pm 0.201 \\
\hline Albumin $(\mathrm{g} / \mathrm{dl})$ & 4.21 & 4.66 & 4.47 & \pm 0.144 \\
\hline Globulin (g/dl) & 4.32 & 4.06 & 4.00 & \pm 0.166 \\
\hline Glucose (mg/dl) & 79.13 & 75.50 & 77.95 & \pm 2.30 \\
\hline Cholesterol (mg/dl) & 149.50 & 138.26 & 146.10 & \pm 3.261 \\
\hline $\operatorname{AST}(\mathrm{U} / \mathrm{I})$ & 68.23 & 66.50 & 67.26 & \pm 0.630 \\
\hline $\operatorname{ALT}(\mathrm{U} / \mathrm{I})$ & 58.60 & 54.53 & 56.60 & \pm 2.128 \\
\hline Uric acid (mg/dl) & $4.66^{\mathrm{a}}$ & $4.10^{\mathrm{b}}$ & $4.29^{\mathrm{ab}}$ & \pm 0.155 \\
\hline Creatinine $(\mathrm{mg} / \mathrm{dl})$ & $1.58^{\mathrm{a}}$ & $1.33^{\mathrm{c}}$ & $1.43^{b}$ & \pm 0.016 \\
\hline
\end{tabular}




\section{CONCLUSION}

It could be concluded that $1 \%$ chicory addition into the required concentrate feed mixture could be useful as it improved nutrient digestibility, growth performance and milk production and its composition of dairy goats. Moreover, chicory addition appears to reflect a good hepatic function that correlate very well with high productive performance.

\section{REFERENCES}

AOAC (1995). Association of Official Analytical Chemists, $16^{\text {th }}$ ed. Official Methods of Analysis, Washington, DC, USA.

Allam, M. Sabbah,; H. M. EL-Banna and Randa R. E. EL-Elamie (2007). Performance of Zaraibi Kids fed diets supplemented with medicinal herbs. Egyptian J. Nutr. and Feeds, 10(2) Special issue: 349363.

Allian, C. C.; L. S. Poon; C. S. G. Chan and W. Richmond (1974). Enzymatic determination of total serum cholesterol. Clin. Chem., 20:470-475.

Ando, S.; T. Nishida; M. Ishida; K. Hosoda and E. Bayaru (2003). Effect of peppermint feeding on the digestibility, ruminal fermentation and protozoa Livest. Prod. Sci., 82:245-248.

Armstrong, W. D. and C. W. Carr (1964). Physiological Chemistry:Laboratory directions 3rd ed , Burgers Publishing Co.Minneapolis, Minnesota, USA.

Athanasiadou, S.; D. Gray; D. Younie; O. Tzamoloukas; F. Jackson and I. Kyriazakis (2007). The use of chicory for parasite control in organic ewes and their lambs. Parasitology, 134: 299-307.

Attia, Y.A.; R.S. hamed; A.E. Abd El-Hamid; H.A. Shahba and F. Bovera (2014). Effect of inulin and mannanoligosaccharides in comparison to Zinc-bacitracin on growing performance, nutrient digestibility and heamatological profiles of growing rabbits. Anim. Prod. Sci. DOI 10.1071/AN13286.

Behboud Jafari1, Ali rezaie and Elmira Habibi (2011). Comparative effect of chicory (Cichorium intybus L.) and nigella sativa extract with an antibiotic on different parameters of broiler chickens, J. Appl. Environ. Biol. Sci., 1(11)525-528.

Boraei, M. A.; M. Fouda and M. A. I. El-Syss (2013).Effect of medicinal herbs supplementation on the feeding value and the performance of local crossbred male lambs. Egyptian J. Nutr. and Feeds, 16(3):427-436

Castellini, C.; R. Cardinali; P.G. Rebollar; A. Dal Bosco; V. Jimeno and M.E. Cossu (2007). Feeding fresh chicory (Chicorium intybus) to young rabbits: performance, development of gastro-intestinal tract and immune functions of appendix and Peyer's patch. Animal Feed Science and Technology. $134,56-65$.

Clark D.A.; C.B. Anderson and T. Berquist (1990). Growth rates of Grasslands Puna'chicory (Cichorium intybus L.) at various cutting intervals and heights and rates of nitrogen. N. Z. J. Agric. Res., 33: 213217.

Coles, E. H. (1986).Veterinary Clinical Pathology, $4^{\text {th }}$. ED. W.B. Saunders Company, London.

Collomb, M.; U. Bütikofer; R. Sieber; B. Jeangros and J. O. Bosset (2002). Correlation between fatty acids in cows' milk fat produced in the Lowlands, Mountains and Highlands of Switzerland and botanical composition of the fodder. International Dairy Journal, 12: 661-666. 
Di Grigoli, A.; M. Todaro; G. Di Miceli; V. Genna; G. Tornambe; M.L. Alicata; D. Giambalvo and A. Bonanno (2012). Effects of continuous and rotational grazing of different forage species on ewe milk production. Small Rumin. Res., 1065: 529-536.

Doumas, B.T.; W.A. Watson and H.G. Biggs (1971). Albumin standareds and measurement of serum with bromocresol green. Clin. Chem. Acta, 31(1): 87-96.

Duncan, D.B. (1955). Multiple ranges and multiple F- test. Biometric, 11:1-42.

Dylan Laws and Liz Genever (2013). Using chicory and plantain in beef and sheep system. Brp@eblex.ahdb.org.uk www.eblex.org.uk

El-Basiony A.Z.; H.M. Khattab; A.M. Kholif; Fatma I. I. Hadhoud and H.A. El-Alamy (2015). Effect of using Echinacea purpurea, Nigella sativa and Chicorium intybus in dairy goats' diet on milk production and quality: 2- effect on digestibility, some blood parameters and milk production and quality. Egyptian J. Nutrition and Feeds, 18(2) Special issue: 137-145.

El-Bordeny, N. E.; M. M. Khorshed; A. N. Sayed and A. A. Aboul Ella (2008). Influence of feeding Rahmany lambs on rations contained different levels of Chamomile flowers. Egyptian J. Nutr. and Feeds, 11(2):343-352.

El-Saadany, S.A.; A.A.M. Habeeb; E.S. El-Gohary; M.M. El-Deeb and K.M. Aiad (2008). Effect of supplementation with oregano or Nigella Sativa seeds to diets of lactating Zaraibi goats on milk yield and some physiological functions during summer season. Egyptian J. Anim. Prod., 45 Suppl. Issue, Dec,:469.

Guermah and Maertens (2012). Dried chicory pulp as fibre source in fattening rabbit diets, Proceedings $10^{\text {th }}$ World Rabbit Congress - September 3 - 6, 2012- Sharm El- Sheikh -Egypt, 495 - 499.

Hanafy, M. A.; G. M. Abdul-Aziz; H. M. Saleh; M. M. M. Mostafa and M. M. Shaaban (2009). Effect of lemongrass (Cymbopogon citratus) and Rosemary (Rosmarinus officinalis) as feed additives on lambs performance. Egyptian J. Nutr. and Feeds, 12(2):297-307.

Henry, R.J.; D.C. Cannon and W. Winkelman (1974). Clinical chemistry principals and techniques, $11^{\text {th }}$ ed. Happer and Row Publishers, New York, USA, pp. 1629.

Hristov, A. N.; T. A. McAllister; F. H. Van Herk; K. J. Cheng; C. J. Newbold and P. R. Cheeke (1999). Effect of Yucca shidigera on ruminal fermentation and nutrient digestion in heifers. J. Anim. Sci., 77:2554-2563.

Ivarsson, E.; B. E. Frankow-Lindberg.; H. K. Andersson and J. E. Lindberg (2011). Growth performance, digestibility and faecal coliform bacteria in weaned piglets fed a cereal-based diet including either chicory (Cichorium intybus L) or ribwort (Plantago lanceolata L) forage. Animal, 5:4: 558-564.

Kralik, G.; G. Kusec; M. Grčevic; I. Durkin and I. Kralik (2012). Animal products as conventional and functional food-An overview. $20^{\text {th }}$ Int. Symp. "Animal Science Days", Kranjska gora, Slovenia, Sep. $19^{\text {th }} 21^{\text {st }}$.

Ling, E. R. (1963). A Text Book of Dairy Chemistry. $3^{\text {rd }}$ Ed. Chapman and Hall. LTD, London.

Mahmoud, M.M. Yasmin. (2017). Effect of dietary supplementation of dried chicory (Cichorium intybus L.) leaves in diets on growth performance of rabbits. J. Animal and Poultry Prod., Mansoura Univ., Vol.8 (4): $69-77$.

Mahmoud, M.M. Yasmin.; M.H.M.Yacout, Azza, M. Kamal; E. A. EL-Bltagy; O. Abdel-Salam and H. B. Mohamed (2014). Effect of basil as feed additive on digestibility, cows performance, growth and diarrhea incidence of their suckling calves. Egyptian J. Nutr. and Feeds, 17(3) 445-455. 
Majenier method laboratory manual (1949). Method of analysis of milk and its products. Milk industry foundation. Washington, DC, USA.

Minnee, E.M.K.; G.C.Waghorn; J.M. Lee and C.E.F. Clark (2017). Including chicory or plantain in perennial ryegrass/White clover-based diet of dairy cattle in late lactation: Feed intake, milk production and rumen digestion. Animal Feed Science and Technology. http:/dx.doi.org/10.1016/j.anifeedsci.2017.03.008.

Molan, A.L.; A.J. Duncan, T.N. Barry and W.C. McNabb (2003). Effects of condensed tannins and crude sesquiterpene lactones extracted from chicory on the motility of larvae of deer lungworm and gastrointestinal nematodes. Parasitol Int. Sep., 52(3):209-18.

NRC (1989). National Research Council. Nutrient Requirement of Dairy Cattle. $7^{\text {th }}$ Ed.. National Academy Press. Washington, DC., USA.

Reitman, S. and S. Frankel (1957). A colorimetric method for determination of serum glumaticoxaloacetic and glutamic pyruvic transaminases. Ann. Journal of clinical pathology, 26:1-13.

Sanderson M.A.; M. Labreveux; M.H. Hall and G.F. Elwinger (2003). Nutritive value of chicory and English plantain forage. Crop Sci., 43: 1797-1804.

SAS (2000). Institute, Inc. SAS-User's Guide: Statistics. SAS Instute Inc., Cary, NC., USA.

Scharenberg, A.; Y. Arrigo; A. Gutzwiller; C.R. Soliva; U. Wyss; M. Kreuzer and F. Dohme (2007). Palatability in sheep and in vitro nutritional value of dried and ensiled sainfoin (Onobrychis viciifolia) birdsfoot trefoil (Lotus corniculatus) and chicory (Cichorium intybus). Arch. Anim. Nutr., 61: 481496.

Sitzia, M.; S. Ligios and N. Fois (2006). Sulla and chicory production and quality under sheep grazing management. In: Loveras J, Gonzales Rodriguez A, Vazque-Janez O, Pineiro J, Santamaria O, Olea $L$, Poblaciones MJ, editors. Sustainable Grassland Productivity. Proceedings of the $21^{\text {st }}$ General Meeting of the European Grassland Federation.; Badajoz, Spain, pp. 448-450.

SooBo, S. (2005): Effects of prebiotics, probiotics and synbiotics in the diet of young pigs \{dissertation\} Wageningen (Netherlands): Wageningen University.

Stroev, E. A. (1989). Biochemistry Text Book, MIR Publishers, MOSCOW.

Tietz, N. W. (1986). Text book of Clinical Chemistry, Saunders, Philadelphia.

Van Kulen, J. and B. A. Young (1977). Evaluation of acid insoluble ash as a natural marker in ruminant digestibility studies. J. Animal Sci., 44:2.

Volk, Z. and M. Marounek (2011). Dried chicory root (Cichorium intybus L.) as a natural fructan source in rabbit diet: Effects on growth performance, digestion and caecal and carcass traits. World Rabbit Sci., 19-143-150.

Wang, Y.; T. A. McAllister; L. J. Yanke; Z. Xu; P. R. Cheeke and K. J. Cheng (2000). In vitro effects of steroidal saponins from Yucca schidigera extract on rumen microbial protein synthesis and ruminal fermentation. J. Sci. Food Agric., 80:2114-2122.

Yusrizal, C. and C. Chen (2003). Effects of adding chicory fructans in feed on broiler growth performance, serum cholesterol and intestinal length. Intr. J. Poult. Sci., 2: 214-219. 


\section{تأثير إضافة أوراق الثيكوريا الجافة للعلاثق علي أداء الماعز الحلابة}

ياسمين محمود تحمد محمود

معه بحوث الإنتاج الحيوانى- مركز البحوث الزراعيةـ وزارة الزراعةـ الاقىـ- جيزة- مصر.

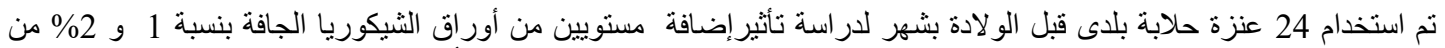

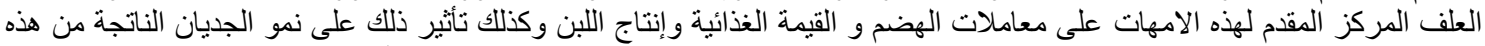

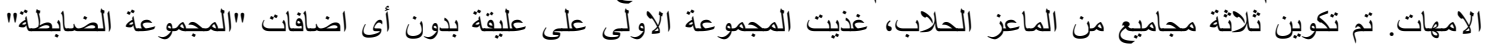

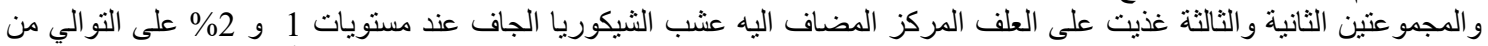
العلف المركز. و غذيت الماعز بمعدل 2,5\% من وزن جسمها علف مركز بالاضافة الى 3 كجم برسيم/يوم/للأس أس وذلك لتنطية احتياجيات

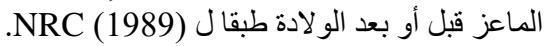

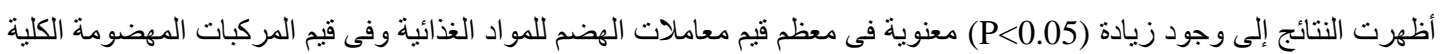

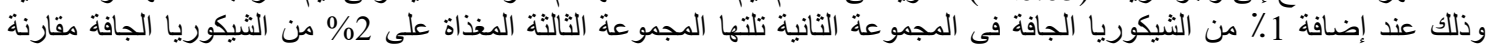
بالمجمو عة الضابطة (المقارنة).

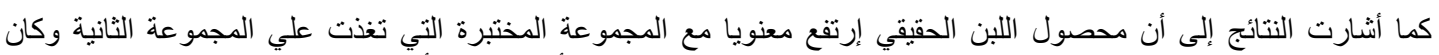

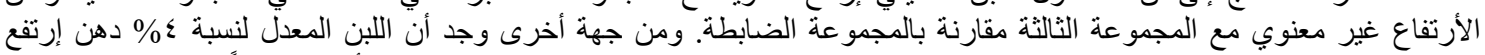

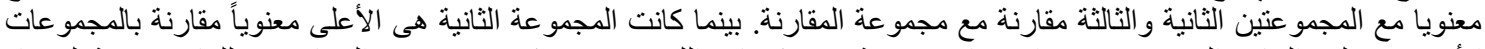

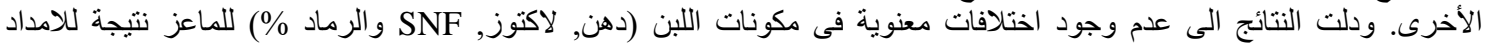

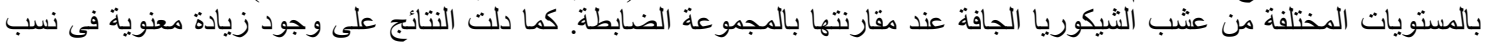

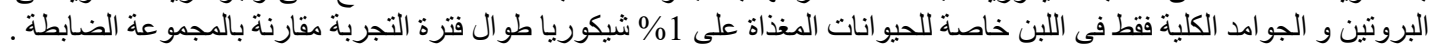

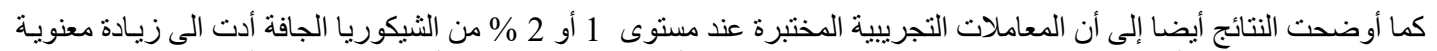



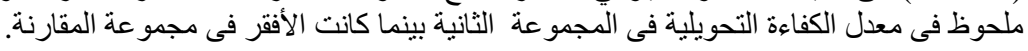

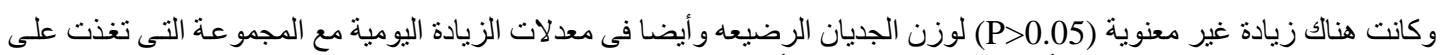

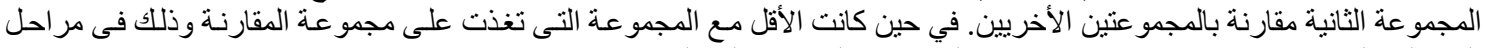


نخلص من هذه النتائج أنه يمكن اضافة عشب الثيكوريا عند مستوى 1 ٪ من العلف المركز في علائق الماعز الحلابة ونتاجها. 